\title{
FAKTOR DETERMINAN YANG MEMPENGARUHI MOTIVASI PELAKSANANA ZIS DI NU CARE-LAZISNU KABUPATEN KENDAL
}

\author{
${ }^{1}$ Muhammad Fauzi \\ ${ }^{2}$ Nurul Khusni Afida \\ ${ }^{3}$ Ageng Prasetyo \\ ${ }^{1}$ Prodi Manajemen FEB UNISS, ${ }^{2}$ Prodi Manajemen FEB UNISS ${ }^{3}$ FEB UNISS \\ ${ }^{1}$ fauzinahrowisaid@gmail.com ${ }^{2}$ Nurulkhusniafida08@gmail.com ${ }^{3}$ agengprasetyo@gmail.com
}

\begin{abstract}
ABSTRAK
Penelitian ini bertujuan untuk menguji adanya pengaruh tingkat pendidikan, religiusitas dan pendapatan terhadap motivasi Masyarakat Kendal dalam menuanikan zakat, infaq dan sedekah. Penelitian ini melakukan pengumpulan data dengan penyebaran kuesioner pada 88 muzzaki di lembaga NU CARE-LAZISNU Kabupaten Kendal. Variabel dependennya adalah motivasi berzakat, infaq dan sedekah, Variabel independentnya adalah tingkat pendidikan, religiusitas dan pendapatan. Teknik pengujian data yang digunakan dalam penelitian ini menggunakan uji validitas, uji reliabilitas, uji asumsi klasik dan analisis regresi berganda dan hipotesis di uji dengan $\mathrm{t}$ test dan $\mathrm{F}$ test dan $\mathrm{R}^{2}$.

Hasil penelitian menunjukan bahwa tingkat pendidikan tidak berpengaruh secara signifikan terhadap motivasi berzakat, infaq dan sedekah. Adapun religiusitas dan pendapatan berpengaruh signifikan terhadap motivasi berzakat, infaq dan sedekah. Secara simultan tingkat pendidikan, religiusitas dan pendapatan berpengaruh positif terhadap motivasi berzakat, infaq dan sedekah. Hasil Adjusted $R$ square menunjukkan bahwa tingkat pendidikan, religiusitas dan pendapatan besarnya terhadap motivasi berzakat, infaq dan sedekah. Hal ini ditunjukan dalam persentase pada pengaruh tingkat pendidikan, religiusitas dan pendapatan sebesar $72,8 \%$, sedangkan sisanya sebesar $27,2 \%$ di pengaruhi oleh variabel lain yang tidak diteliti.
\end{abstract}

Kata Kunci: ZIS, Tingkat Pendidikan, Motivasi

\begin{abstract}
This study aims to examine the existence of the influence of the level of education, religiosity and income on the motivation of giving ZIS (zakat, infak ad sedekah) of Kendal people. This study collected data by distributing questionnaires to 88 muzzaki in the NU CARE-LAZISNU institution Kendal Regency. The dependent variable is the motivation to give zakat, infaq and sedekah. The independent variables are the level of education, religiosity and income. The data testing technique used in this research is validity test, reliability test, classical assumption test and multiple regression analysis and the hypothesis is tested by $t$ test and $F$ test and $R 2$.

The results showed that the level of education did not have a significant effect on the motivation to give zakat, infaq and sedekah. On the other hand, Religiosity and income have a significant effect on the motivation to give zakat, infaq and alms. Then, the level of education, religiosity and income simultaneously have a positive effect on the motivation to give zakat, infaq and sedekah. The results of the Adjusted $R$ square show that the level of education, religiosity and income is the amount of motivation to give zakat, infaq and sedekah. This is shown in the percentage of the influence of education level, religiosity and income of $72.8 \%$, while the remaining $27.2 \%$ is influenced by other variables not examined.
\end{abstract}

Keywords : ZIS, Level of Education, Motivation 


\section{PENDAHULUAN}

Kemiskinan dan ketimpangan pendapatan merupakan persoalan rumit yang dihadapi oleh negara, Sifatnya masif dan struktural serta meluas yang terjadi pada setiap lapisan masyarakat, oleh karena itu karena negara mempunyai danmemegang kekuasaan sekaligus kekuasaan ekonomi paling besar, Sehingga negaralah yang sewajarnya mengemban tugas mulia untuk mengentaskan kemiskinan, Sekalipun begitu, tidak menutup kemungkinan setiap lapisan masyarakat mempunyai peranan yang signifikan dalam mengentaskan kemiskinan, bahkan peran agama juga sangat dimungkinkan dalam hal ini, salah satunya ditunjukan dalam ajaran islam tentang zakat infaq dan sedekah, penerapan itu sangat signifikan dalam mengurangi masalah kemiskinan.

Seseorang yang beruntung mendapatkan sejumlah harta pada hakekatnya hanya menerima titipan sebagai amanat untuk disalurkan sesuai dengan kehendak pemiliknya Allah SWT. Koneksinya manusia yang kepadanya dititipkan harta tersebut harus memenuhi aturan aturan Allah baik dalam pengembangan maupun dalam penggunaanya, antara lain ada kewajiban yang dibedakan kepada pemiliknya untuk mengeluarkan zakat untuk kesejahteraan masyarakat, dan ada ibadah amaliyah sunnah seperti sedekah dan infaq (zuhri, 2012).

Zakat sebagai instrument perekonomian islam yang diharapkan dapat menjdi jembatan antara yang kaya dan yang miskin untuk mengatasi masalah kemiskinan malah menjadi polemik yang masih menarik untuk dibicarakan yang dari tahun ke tahun selalu aja ada kejadian yang berhubungan dengan zakat (fifi, 2015)

Tujuan zakat tidak hanya sekedar menyantuni orang miskin secara konsumtif tetapi juga memiliki tujuan permanen yaitu menuntaskan kemiskinan dan dapat mengangkat derajat fakir miskin dengan membantu keluar dari kesulitan hidup. Zakat merupakan institusi resmi yang diarahkan untuk menciptakan pemerataan dan keadilan bagi masyarakat, sehingga taraf kehidupan masyarakat dapat ditingkatkan. (wulansari,2014)

Dalam meningkatkan potensi zakat maka diperlukan sebuah lembaga yang mampu mengelola dana zakat untuk mendistribusikannya kepada yang berhak mendapatkan zakat. Di Indonesia pengelolaan lembaga amil zakat diatur dalam undang-undang RI Nomor 23 tahun 2011 tentang pengelolaan zakat pasal 15 ayat (1) salah satu lembaga keuangan syariah yang bertugas menghimpun dana masyarakat (zakat) dam 
mendistribusikannya kembali adalah lembaga amil zakat dan badan amil zakat. Adanya lembaga ini bertujuan menghimpun dana dari masyarakat yang berupa zakat, infaq, shadaqoh yang akan disalurkan kembali pada masyarakat yang kurang mampu.

Di Indonesia, terdapat lembaga semi-pemerintah yang berwenang untuk melakukan pengelolaan dan pendistribusian zakat, yaitu badan amil zakat nasioanal (BAZNAS), disamping itu juga terdapat lembaga swadaya masyarakat yang non pemerintah yang memfokuskan untuk mengurusi zakat, infaq dan shodaqoh yaitu pada organisasi islam Nahdahatul Ulama yaitu lembaga NU CARE-LAZISNU, dan di organisasi islam muhammadiyah juga terdapat lembaga yang sama yaitu LAZISMU. Semakin luasnya pemahaman dan pemberdayaan zakat, infaq dan shodaqoh ini menjadi penting, terutama jika di kaitkan dengan konsep pengembangan zakat, infaq dan shodaqoh (ZIS) yang bertujuan untuk mencapai keadilan sosial dan meningkatkan kesejahteraan umat.

Bukan hanya zakat saja yang fungsi dan tujuannya untuk menyejahterakan umat, infaq dan sedekah pun punya fungsi dan tujuan yang besar dalam rangka menyejahterakan umat dan meminimalisir adanya kemiskinan di Indonesia, untuk itu organisasi terbesar islam di Indonesia yaitu Nahdhatul Ulama membuat atau melahirkan lembaga zakat infaq shodaqoh, bukan hanya zakat yang diurusi tapi infaq dan shodaqoh tujuannya ini salah satunya untuk membedakan atau tidak menyerupai tugas dari BAZNAS.

NU CARE-LAZISNU merupakan rebranding dari lembaga amil zakat, infaq dan shadaqah Nahdhatul Ulama yang berdiri pada tahun 2004, sebagai lembaga kemanusiaan, NU CARE-LAZISNU berkhidmat membantu kesejahteraan dan kemandirian umat. NU CARE-LAZISNU secara yudiris-formal dikukuhkan oleh SK menteri agama no 65/2005 untuk melakukan pemungutan zakat, infaq dan sedekah kepada masyarakat luas.

NU CARE-LAZISNU merupakan lembaga nirbala milik perkumpulan Nahdlatul ulama (NU) yang bertujuan berkhidmat dalam rangka membantu kesejahteraan umat, mengangkat harkat sosial dengan mendayagunakan dana zakat, infaq, sedekah serta wakaf (ziswaf) dan sampai saat ini NU CARE-LAZISNU telah memiliki jaringan pelayanan dan pengelolaan ZIS di 12 negara, 34 provinsi dan 376 kabupaten/kota di Indonesia, NU CARE-LAZISNU sebagai lembaga filantropi akan terus berupaya untuk meningkatkan kepercayaan dari para donatur yang semua 
sistem pencatatan dan penyalurannya akan bisa dilihat secara real time melalui sistem IT.

Permasalahan yang sering muncul ditengah masyarakat kita adalah kepada siapa zakat harus diberikan. Lebih utama disalurkan langsung oleh muzzaki kepada mustahiq, atau sebalinya melalui amil zakat. Jika disalurkan kepada mustahiq memang ada perasaan tenang karena menyaksikan secara langsung zakatnya tersebut telah disalurkan kepada mereka yang dianggap berhak menerimanya. Tapi terkadang pemnyaluran langsung dilakukan oleh muzzaki tidak mengenai sasaran yang tepat, terkadang orang sudah merasa menyalurkan zakat kepada mustahiq, padahal ternyata yang menerima bukan mustahiq yang sesungguhnya, hanya karena kedekatan emosi maka ia memberikan zakat kepadanya, misalnya disalurkan kepda kerabatnya sendiri yang menurut anggapnya sudah termasuk kategori mustahiq, padahal jika dibandingkan dengan orang yang berada dilingkungan sekitarnya masih banyak orang-orang yang lebih menderita dibandingkan dengan kerabatnya tersebut.

Berikut ini adalah Data perolehan zakat, infaq dan sedekah berdasarkan data dari

NU CARE-LAZISNU KENDAL.

Data Perolehan Zakat, Infaq dan Sedekah

\begin{tabular}{|c|c|c|c|c|c|}
\hline Tahun & 2016 & 2017 & 2018 & 2019 & 2020 \\
\hline Jumlah & - & - & 105.926 .000 & 145.753 .000 & 45.436 .900 \\
\hline
\end{tabular}

Sumber: Nu Care - Lazisnu Kabupaten Kendal

Kurang optimalnya jumlah zakat, infaq dan sedekah yang terkumpul disebabkan oleh beberapa hal, antara lain: pertama ketidaktahuan kewajiban membayar zakat, ada sebagian masyarakat yang tidak tahu bahwa dia harus membayar zakat, mereka hanya tahu bahwa zakat itu hanyalah zakat fitrah dibulan ramadhan, bahwa sebenarnya ada ada kewajiban membayar zakat lainnya yang mereka belum tahu. Kedua, ketidakmauan memberikan zakat, infaq dan sedekah, atau rendahnya motivasi berzakat, infaq dan sedekah, terdapat sebagian masyarakat yang enggan untuk memberikan zakat, infaq dan sedekah, ada sebagian masyarakat yang berperilaku kikir. Ketiga, rendahnya pendapatan dari mereka, ketika seseorang merasa pendapatan mereka belum cukup untuk memenuhi kebutuhan sehari-hari 
seseorang enggan atau merasa berat untuk memberikan zakat, infaq maupun sedekah karena mereka pun untuk kebutuhan masih susah padahal untuk memberikan infaq dan sedekah pun tidak ada takarannya, berapa pun akan diterima asal itu ikhlas. Keempat, ketidakpercayaan terhadap lembaga pengelolaan zakat, infaq dan sedekah. Sebagian masyarakat mengeluarkan zakat, infaq dan sedekah langsung ke mustahiq, atau secara perorangan bukan di lembaga amil seperti LAZISNU.

Ada beberapa hal yang kemungkinan mempengaruhi motivasi masyarakat dalam memberikan zakat infaq shodaqoh antaranya, pengaruh pada tingkat pendidikan, religiusitas dan pendapatan masyarakat yang ada di kabupaten Kendal ini maka untuk itu peneliti tertarik mengangkat permasalahan tersebut untuk dilakukan penelitian dengan judul “ Pengaruh Tingkat Pendidikan, Religiusitas dan Pendapatan terhadap Motivasi Berzakat, Infaq dan Sedekah di NU CARE-LAZISNU Kabupaten Kendal “.

\section{METODE PENELITIAN}

Berdasarkan data yang telah diperoleh, penelitian ini termasuk kedalam penelitian kuantitatif dengan sumber data primer dan data sekunder. Pada penelitian ini populasi yang diambil adalah para pemberi zakat, infaq dan sedekah. Sampel penelitian ini menggunakan perhitungan rumus slovin dengan batas toleransi $10 \%$, dan menggunakan teknik sampling yaitu probability sampling yaitu teknik pengambilan sampel dengan memberikan peluang yang sama bagi setiap unsur populasi yang akan menjadi anggota sampel. Adapun metode yang digunakan dalam penelitian ini adalah simple random sampling yaitu dikatakan simple (sederhana) karena pengambilan simple dari populasi dilakukan secara acak tanpa memperhatikan strata yang ada di populasi. Adapun kriteria sampel yang ditetapkan adalah responden yang memberikan zakat, infaq dan sedekah dan yang sudah baligh berusia 18 tahun ke atas dianggap sudah mencukupi umur. responden berdomisili di Kendal. Pengumpulan data berupa dengan penyebaran kuisioner dan wawancara terhadap responden dalam penelitian ini yaitu para pemberi zakat, infaq dan sedekah.

Pada penelitian ini uji analisis data menggunakan uji instrumen ada dua konsep untuk mengukur kuliatas data yaitu berupa, uji validitas yaitu suatu alat ukur yang digunakan untuk mengukur sah/valid tidaknya kuesioner,uji reliabilitas menunjukan suatu pengertian bahwa reliabilitas sebenarnya adalah alat untuk 
mengukur suatu kuesioner yang merupakan indikator dari variabel atau konstruk (Imam ghozali, 2011). Uji asumsi klasik yang meliputi,uji Normalitas untuk menguji apakah sampel yang digunakan memiliki distribusi yang normal atau tidak, uji Multikolinearitas untuk untuk menguji apakah dalam model regresi ditemukan ada atau tidaknya korelasi antara variabel bebas,dan uji Heterokedatisitas menguji apakah dalam model regresi terjadi ketidaksamaan varians dan residual satu pengamatan ke pengamatan lain.Regresi linier berganda (Sugiyono,2011) yaitu suatu uji yang digunakan penelitian dengan maksud meramalkan bagaimana keadaan (naik turunnya) variabel independen sebagai faktor predictor dimanipulasi atau bisa disebut juga suatu uji dimana untuk mengetahui pengaruh antara variabel bebas terhadap variabel terikat. Kemudian ada uji hipotesis yang meliputi, uji $t$ adalahUji statistik t pada dasarnya menunjukan seberapa jauh pengaruh suatu variabel penjelas/independen secara individual dalam menerangkan variasi variabel dependen, uji $\mathrm{F}$ pada dasarnya menunjukkan apakah semua variabel independen atau bebas yang dimasukkan dalam model mempunyai pengaruh secara bersamasama terhadap variabel dependen, selanjutnya koefisien determinasi $\left(\mathrm{R}^{2}\right)$ pada intinya mengukur seberapa jauh kemampuan model dalam menerangkan variasi variabel dependen. Nilai determinasi adalah antara nol dan satu.

\section{Jenis Penelitian}

Untuk penelitian ini, peneliti menggunakan pendekatan deskriptif kuantitatif, yaitu pendekatan yang analisisnya pada data-data numerical (angka) yang diolah dengan metode statistika. Dengan metode kuantitatif akan diperoleh signifikansi perbedaan kelompok atau signifikansi hubungan antar variabel independen yang diteliti. Dalam penelitian ini terdapat tiga variabel independen dan satu variabel dependen. Variabel independen pada penelitian ini yaitu, tingkat pendidikan, religiusitas dan pendapatan. Untuk variabel dependen yaitu motivasi ber zakat, infaq dan sedekah di NU CARELAZISNU Kendal

\section{Waktu dan Tempat Penelitian}

Penelitian ini dilaksanakan di Kabapaten Kendal Jawa Tengah, dengan melibatkan para muzakki yang memberikan donasinya dalam bentuk ZIS zakat infak dan sedekah melalui lembaga NU-Care LAZISNU Kabupaten Kendal. Penelitian dilaksanakn dalam kurun waktu 3 bulan, terhitung mulai Juli-Oktober 2020

\section{Target/Subjek Penelitian}

Penelitian melibatkan semua yang melakukan aktifitas ZIS melalui NU-Care 
LAZISNu Kabupaten Kendal. Responden yang terlibat dalam penelitian ini berjumlah 88 muzakki yang pernah mellaukan aktifitas Donasi mellaui NU CARE LAZISNU Kabupaten Kendal.

\section{Data, Instrumen, dan Teknik Pengumpulan Data}

Ada dua konsep untuk mengukur kualitas data, yaitu uji validasi dan reliabilitas. Artinya suatu penelitian akan menghasilkan kesimpulan yang bisa jika datanya kurang reliable dan kurang valid, sedangkan kualitas dalam penelitian ditentukan oleh kualitas instrumen yang digunakan untuk mengumpulkan data. Instrumen yang baik harus memenuhi dua persyaratan penting yang valid dan reliable. Kuesioner yang digunakan dalam penelitian ini telah diuji validitas dan reliabilitas tetap dilakukan karena pertimbangan perbedaan waktu, obyek dan kondisi yang dialami oleh peneliti sekarang dan peneliti sebelumnya.

\section{Teknik Analisis Data}

Metode pengumpulan data yang digunakan dalam penelitian ini adalah angket atau kuisioner. Kuisioner merupakan suatu bentuk instrument pengumpulan data yang sangat fleksibel dan relative mudah digunakan. Data yang diperoleh lewat penggunaan kuisioner adalah data yang dikategorikan sebagai data factual. Oleh karena itu, realibitas hasilnya sangat banyak tergantung pada subjek penelitian sebagai responden sedangkan pihak peneliti dapat mengupayakan peningkatan reabilitas itu dengan cara penyajian kalimat-kalimat yang jelas dan disampaikan dengan strategi yang tepat (Riduwan,2013)

Teknik ini merupakan bentuk alat pengumpulan data dalam pertanyaanpertanyaan. Diharapkan dengan menyebarkan daftar pertanyaan kepada setiap responden, peneliti dapat menghimpun data yang relevan dengan tujuan penelitian memilikitingkat reabilitas dan validitas yang tinggi (Muhammad, 2013) Pertanyaan yang disediakan dalam kuisioner berkaitan dengan variabel penelitian yaitu tentang pengaruh tingkat pendidikan, religiusitas dan pendapatan terhadap motivasi berzakat, infaq dan sedekah di NU CARE-LAZISNU Kabupaten Kendal.

\section{HASIL}

\section{Hasil Uji Instrumen}




\begin{tabular}{|c|c|c|c|c|}
\hline Variabel & Indikator & r hitung & $r$ tabel & Keterangan \\
\hline \multirow{5}{*}{$\begin{array}{l}\text { Tingkat } \\
\text { Pendidikan } \\
\text { (X1) }\end{array}$} & $\mathrm{X} 1.1$ & 0,790 & 0,209 & Valid \\
\hline & $\mathrm{X} 1.2$ & 0,859 & 0,209 & Valid \\
\hline & $\mathrm{X} 1.3$ & 0,783 & 0,209 & Valid \\
\hline & $\mathrm{X} 1.4$ & 0,868 & 0,209 & Valid \\
\hline & X1.5 & 0,867 & 0,209 & Valid \\
\hline \multirow{5}{*}{$\begin{array}{l}\text { Religiusitas } \\
\text { (X2) }\end{array}$} & $\mathrm{X} 2.1$ & 0,784 & 0,209 & Valid \\
\hline & $\mathrm{X} 2.2$ & 0,779 & 0,209 & Valid \\
\hline & $\mathrm{X} 2.3$ & 0,792 & 0,209 & Valid \\
\hline & X2. 4 & 0,731 & 0,209 & Valid \\
\hline & $\mathrm{X} 2.5$ & 0,738 & 0,209 & Valid \\
\hline \multirow{3}{*}{$\begin{array}{c}\text { Pendapatan } \\
\text { (X3) }\end{array}$} & X3.1 & 0,810 & 0,209 & Valid \\
\hline & X3.2 & 0,919 & 0,209 & Valid \\
\hline & X3.3 & 0,848 & 0,209 & Valid \\
\hline \multirow{5}{*}{$\begin{array}{c}\text { Motivasi } \\
\text { BerZIS (Y) }\end{array}$} & Y1 & 0,774 & 0,209 & Valid \\
\hline & Y2 & 0,740 & 0,209 & Valid \\
\hline & Y3 & 0,771 & 0,209 & Valid \\
\hline & Y4 & 0,703 & 0,209 & Valid \\
\hline & Y5 & 0,678 & 0,209 & Valid \\
\hline
\end{tabular}

Berdasarkan tabel diketahui bahwa hasil perhitungan $\mathrm{r}$ hitung semua lebih besar dari $\mathrm{r}$ tabel yaitu $\mathrm{df}=(\mathrm{n}-2)$ yaitu : $88-2=86$ dengan tingkat signifikansi $<0,05$ diperoleh nilai $r$ tabel $=0,209$. Hal ini dapat disimpulkan bahwa semuavariable atau indikator dalam penelitian ini dinyatakan valid. yang artinyaindikator dari variabel tingkat pendidikan (X1), religiusitas (X2), pendapatan(X3), dan motivasi 
berzakat, infaq dan sedekah (Y) dalam kuesioner tersebut sahsebagai alat ukur.

\section{Uji Reliabilitas}

\begin{tabular}{|l|c|c|}
\hline \multicolumn{1}{|c|}{ Variabel } & Cronbach Alpha & Keterangan \\
\hline Tingkat Pendidikan (X1) & 0,884 & Reliabel \\
\hline Religiusitas (X2) & 0,822 & Reliabel \\
\hline Pendapatan (X3) & 0,824 & Reliabel \\
\hline Motivasi BerZIS (Y) & 0,783 & Reliabel \\
\hline
\end{tabular}

Berdasarkan tabel diketahui bahwa nilai cronbach's alpha dari seluruh variabel yang diujikan nilainya sudah diatas dari 0,60, maka dapat disimpulkan bahwa seluruh variabel dalam penelitian ini yakni tingkat pendidikan, religiusitas, pendapatan dan motivasi berzakat, infaq dan sedekah lolos dalam uji reliabilitas dan dinyatakan reliabel, yang artinya indikator dari variabel tingkat Pendidikan (X1), religiusitas (X2), pendapatn (X3), dan motivasi berzakat, infaq dan sedekah (Y) yang digunakan dalam kuesioner mampu menghasilkan jawaban yang konsisten bila dilakukan berulang kali sehingga dapat digunakan untuk pengambilan data penuh.

\section{Uji Asumsi klasik}

\section{Uji Normalitas}

One-Sample Kolmogorov-Smirnov Test

\begin{tabular}{|ll|r|}
\hline & & $\begin{array}{r}\text { Unstandardize } \\
\text { d Residual }\end{array}$ \\
\hline Normal Parameters & & 88 \\
& & Mean \\
Most Extreme Differences & Std. Deviation & .0000000 \\
& Absolute & 1.06488564 \\
& Positive & .087 \\
Kolmogorov-Smirnov Z & Negative & .087 \\
& & -.083 \\
& & .816
\end{tabular}


a. Test distribution is Normal.

b. Calculated from data.

Dari tabel diatas dapat dilihat bahwa nilai signifikan dibagian kolmogorov sebesar 0,518, maka dapat disimpulkan bahwa dalam penelitian ini data distribusi normal, karena nilai signifikansi 0,518>0,05, maka dapat disimpulkan bahwa dalam penelitian ini data distribusi normal.

\section{Uji Multikolonieritas}

\begin{tabular}{|c|c|c|c|c|c|c|c|}
\hline & & & Coefficients & & & & \\
\hline \multirow[b]{2}{*}{ Model } & \multicolumn{2}{|c|}{$\begin{array}{l}\text { Unstandardize } \\
\text { d Coefficients }\end{array}$} & \multirow{2}{*}{\begin{tabular}{|c} 
Standardized \\
Coefficients \\
Beta
\end{tabular}} & \multirow[b]{2}{*}{$\mathrm{t}$} & \multirow[b]{2}{*}{ Sig. } & \multicolumn{2}{|c|}{$\begin{array}{r}\text { Collinearity } \\
\text { Statistics }\end{array}$} \\
\hline & B & $\begin{array}{l}\text { Std. } \\
\text { Error }\end{array}$ & & & & Tolerance & VIF \\
\hline 1 (Constant) & 8.880 & 1.005 & & 8.836 & .000 & & \\
\hline Pendidikan & -.442 & .080 & -.609 & -5.524 & .000 & .257 & 3.887 \\
\hline Religiusitas & .322 & .072 & .382 & 4.464 & .000 & .428 & 2.336 \\
\hline Pendapatan & 1.185 & .113 & 1.034 & 10.470 & .000 & .321 & 3.117 \\
\hline
\end{tabular}

a. Dependent Variable: Motivasi

Berdasarkan output diatas diketahui bahwa nilai tolerance variabel tingkat pendidikan (X1), religiusitas (X2), dan pendapatan (X3) lebih besar dari 0,10. Sementara itu, nilai VIF variabel tingkat pendidikan (X1), religiusitas (X2), dan pendapatan (X3) lebih kecil dari 10, sehingga dapat disimpulkan tidak terjadi multikolonieritas.

\section{Uji Heteroskedastisitas}

Coefficients ${ }^{\mathrm{a}}$

\begin{tabular}{|l|c|c|}
\hline Coefficients $^{\mathbf{a}}$ & Unstandardized \\
Coefficients & Standardized \\
Coefficients & & \\
& & \\
\hline
\end{tabular}




\begin{tabular}{|c|c|c|c|c|c|c|}
\hline \multicolumn{2}{|c|}{ Model } & B & Std. Error & Beta & $\mathrm{t}$ & Sig. \\
\hline 1 & (Constant) & 1.075 & .599 & & 1.794 & .076 \\
\hline & Pendidikan & 050 & 040 & & 1057 & 204 \\
\hline & Religiusitas & & & & & \\
\hline & Pendapatan & .040 & .067 & .115 & .600 & .550 \\
\hline
\end{tabular}

a. Dependent Variable: RES2

Berdasarkan output diatas diketahui bahwa nilai signifikansi variabel tingkat pendidikan (X1), religiusitas (X2), dan pendapatn (X3) lebih besar dari 0,05 sehingga tidak terjadi heteroskedastisitas.

\section{Analisis regresi linier berganda}

Coefficients

\begin{tabular}{|c|c|c|c|c|c|c|}
\hline \multirow[b]{2}{*}{ Mode } & & \multicolumn{2}{|c|}{$\begin{array}{l}\text { Unstandardized } \\
\text { Coefficients }\end{array}$} & \multirow{2}{*}{$\begin{array}{c}\text { Standardized } \\
\text { Coefficients } \\
\text { Beta }\end{array}$} & \multirow[b]{2}{*}{$\mathrm{t}$} & \multirow[b]{2}{*}{ Sig. } \\
\hline & & B & Std. Error & & & \\
\hline \multirow[t]{4}{*}{1} & (Constant) & 8.880 & 1.005 & & $8.83 d$ & .000 \\
\hline & Pendidikan & -.442 & .080 & -.609 & -5.524 & .000 \\
\hline & Religusitas & .322 & .072 & .382 & 4.46 & .000 \\
\hline & Pendapatan & 1.185 & .113 & 1.03 & 10.47 & .000 \\
\hline
\end{tabular}

a. Dependent Variable: Motivasi

Berdasarkan tabel 4.15 dapat diketahui bersamaan regresi yang terbentuk adalah :

$\mathrm{Y}=\alpha+\beta 1 \mathrm{X} 1+\beta 2 \mathrm{X} 2+\beta 2 \mathrm{X} 3+\mathrm{e}$

$\mathrm{Y}=8.880-0,442 \mathrm{X} 1+0,322 \mathrm{X} 2+1.185 \mathrm{X} 3+\mathrm{e}$

Dari persamaan koefisien regresi tersebut diatas maka dapat dijelaskan bahwa: 
1. Konstanta sebesar 8.880 artinya jika tingkat pendidikan (X1), religiusitas (X2) dan pendapatan (X3) nilainya adalah 0, maka Motivasi berZIS (Y) nilainya adalah 8.880 .

2. Koefisien regresi variabel tingkat pendidikan (X1) sebesar -0,442 artinya jika tanggapan responden mengenai tingkat pendidikan (X1) ditingkatkan satu satuan maka akan mempengaruhi penurunan motivasi berZIS sebesar 0,442 satuan dengan asumsi variabel lain tidak mengalami perubahan atau konstan..

3. Koefisien regresi variabel religiusitas indikasi kedua yaitu (X2) sebesar 0,322 berarti setiap kenaikan variabel religiuitas (X2) sebesar satu satuan, maka motivasi berZIS akan naik sebesar 0,322 satuan dengan asumsi variabel lain tidak mengalami perubahan atau konstan.

4. Koefisien regresi variabel pendapatan (X3) sebesar 1.185 artinya setiap kenaikan variabel pendapatan sebesar satu satuan, maka motivasi berZIS akan naik sebesar 1.185 satuan dengan asumsi variabel lain tidak mengalami perubahan atau konstan.

\section{Uji Hipotesis}

\section{Uji t (Parsial)}

\section{Coefficients}

\begin{tabular}{|c|c|c|c|c|c|c|}
\hline \multirow{2}{*}{\multicolumn{2}{|c|}{ Model }} & \multicolumn{2}{|c|}{$\begin{array}{l}\text { Unstandardized } \\
\text { Coefficients }\end{array}$} & \multirow{2}{*}{$\begin{array}{l}\text { Standardized } \\
\text { Coefficients } \\
\text { Beta }\end{array}$} & \multirow[b]{2}{*}{$\mathrm{t}$} & \multirow[b]{2}{*}{ Sig. } \\
\hline & & B & Std. Error & & & \\
\hline \multirow[t]{4}{*}{1} & (Constant) & 8.880 & 1.005 & & 8.836 & .000 \\
\hline & Pendidikan & -.442 & .080 & -.609 & -5.524 & .000 \\
\hline & Religusitas & .322 & .072 & .382 & 4.464 & .000 \\
\hline & Pendapatan & 1.185 & .113 & 1.034 & 10.470 & .000 \\
\hline
\end{tabular}

a..Dependent Variable: Motivasi

$\mathrm{t}$ tabel $=(\alpha / 2 ; \mathrm{n}-\mathrm{k}-1)$

$$
\begin{aligned}
& =(0,05 / 2 ; 88-4-1) \\
& =(0,025 ; 83) \\
& =1,98896
\end{aligned}
$$

1. Dari tabel diatas terlihat bahwa hasil pengujian hipotesis mengenai tingkat pendidikan memiliki nilai $\mathrm{t}$ hitung $=-5,524<\mathrm{t}$ table $=1,98896$ dengan taraf signifikansi 0,000 < 0,05, dengan demikian Ho diterima dan Ha ditolak. Hal ini menunjukkan bahwa tingkat pendidikan tidak mempunyai berpengaruh 
dan signifikan terhadap motivasi berzakat infaq dan sedekah di NU CARELAZISNU Kabupaten Kendal.

2. Kemudian untuk variabel religiusitas maka diperoleh nilai $\mathrm{t}$ hitung 4,464>t tabel $=1,98896$ dengan taraf signifikansi $0,000<0,05$, Dengan demikian Ho ditolak dan Ha diterima, hal ini dapat disimpulkan bahwa religiusitas mempunyai pengaruh dan signifikan terhadap motivasi berzakat infaq dan sedekah di NU CARE-LAZISNU Kabupaten Kendal.

3. Kemudian untuk variabel pendapatan maka diperoleh nilai t hitung 10,470> t tabel 1,98896 dengan taraf signifikansi 0,000 < 0,05, dengan demikian Ho ditolak dan Ha diterima. Hal ini dapat disimpulkan bahwa pendapatan mempunyai pengaruh dan signifikan terhadap peningkatan motivasi berzakat infaq dan sedekah di NU CARE-LAZISNU Kabupaten Kendal.

\section{Uji F (Simultan)}

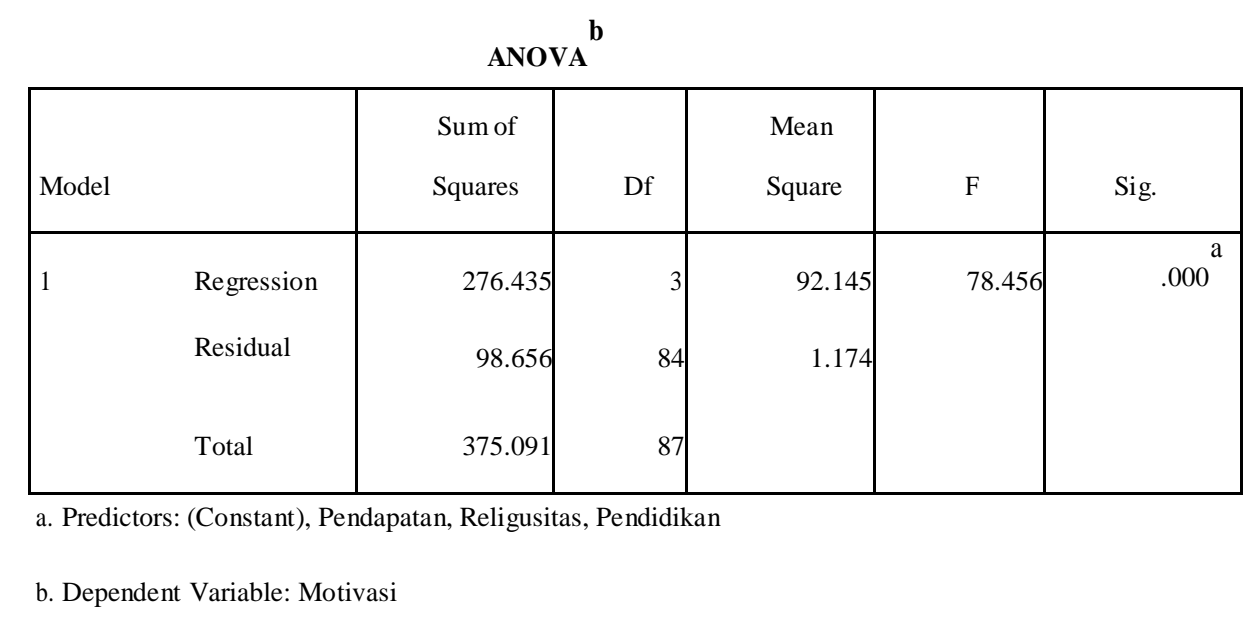

$\mathrm{F}$ hitung $=(\mathrm{k} ; \mathrm{n}-\mathrm{k})$

$=(3 ; 88-3)$

$=(3 ; 85)$

$=2,71$

Pengujian pengaruh variabel bebas secara bersama - sama terhadap variabel terikatnya dengan menggunakan uji F. Hasil perhitungan statistik menunjukkan nilai $\mathrm{F}$ hitung $=78,456>\mathrm{F}$ table $=2,71$ dengan menggunakan batas signifikansi 0,05, maka diperoleh nilai signifikansi $0,000<0,05$, hal ini dapat disimpulkan bahwa tingkat pendidikan, religiusitas dan pendapatan mempunyai pengaruh secara simultan terhadap motivasi berzakat infaq dan sedekah di NU CARE-LAZISNU Kabupaten Kendal. 


\section{Koefisien Determinasi $\left(\mathbf{R}^{2}\right)$}

Model Summary

\begin{tabular}{|l|r|r|r|r|}
\hline & & & & \\
\hline 1 & $\mathrm{R}$ & $\mathrm{R}$ Square & Adjusted R Square & $\begin{array}{c}\text { Std. Error of the } \\
\text { Estimate }\end{array}$ \\
\hline & $.85_{8}^{\mathrm{a}}$ & .737 & .728 & 1.084 \\
\hline
\end{tabular}

a. Predictors: (Constant), Pendapatan, Religusitas, Pendidikan

2

Besarnya hasil analisis koefisien determinasi $(\mathrm{R})$ di peroleh hasil analisis koefisien determinasi (Adjusted R Square) sebesar 0,728 atau (72,8\%). Hal ini menunjukkan bahwa persentase sumbangan pengaruh tingkat pendidikan, religiusitas dan pendapatan terhadap motivasi berZIS sebesar 72,8\%, sedangkan sisanya sebesar $27,2 \%$ di pengaruhi oleh variabel lain yang tidak diteliti.

\section{HASIL PENELITIAN PEMBAHASAN}

\section{Pengaruh secara parsial}

1. Pengaruh tingkat pendidikan terhadap motivasi berzakat, infaq dan sedekah Tingkat Pendidikan tidak berpengaruh positif dan signifikan terhadap motivasi berZIS, terlihat bahwa hasil pengujian hipotesis mengenai tingkat pendidikan memiliki nilai $\mathrm{t}$ hitung $=-5,524<\mathrm{t}$ table $=1,98896$ dengan taraf signifikansi $0,000<0,05$.

2. Pengaruh religiusitas terhadap motivasi berzakat, infaq dan sedekah Religiusitas berpengaruh dan signifikan terhadap motivasi berZIS dengan hasil uji hipotesis variabel religiusitas maka diperoleh nilai t hitung 4,464 > t tabel= 1,98896 dengan taraf signifikansi $0,000<0,05$.

3. Pengaruh pendapatan terhadap motivasi berzakat, infaq dan sedekah Pendapatan berpengaruh signifikan terhadap motivasi berZIS. Dengan hasil uji hipotesis untuk variabel pendapatan maka diperoleh nilai t hitung 10,470>t tabel 1,98896 dengan taraf signifikansi $0,000<0,05$.

\section{Pengaruh Secara Simultan}

Tingkat pendidikan, religiusitas, dan pendapatan mempunyai pengaruh secara simultan terhadap motivasi berzakat, infaq dan sedekah. Hasil perhitungan statistik 
menunjukkan nilai $\mathrm{F}$ hitung $=78,456>\mathrm{F}$ table $=2,71$ dengan menggunakan batas signifikansi 0,05, maka diperoleh nilai signifikansi $0,000<0,005$, dengan ini bahwa tingkat pendidikan, religiusitas, dan pendapatan mempunyai pengaruh secara simultan terhadap motivasi berzakat, infaq dan sedekah di NU CARE-LAZISNU Kabupaten Kendal.

\section{Analisis Koefisien Determinasi}

Hasil analisis koefisien determinasi (Adjusted $R$ square) dalam penelitian ini menunjukkan bahwa tingkat pendidikan, religiusitas, dan pendapatan mempunyai pengaruh yang cukup besar terhadap motivasi berzakat, infaq dan sedekah. Hal ini menunjukkan bahwa persentase sumbangan pengaruh tingkat pendidikan, religiusitas, dan pendapatan terhadap motivasi berzakat, infaq dan sedekah pada sebesar $72,8 \%$, sedangkan sisanya sebesar $27,2 \%$ di pengaruhi oleh variabel lain yang tidak diteliti.

\section{KESIMPULAN DAN IMPLIKASI}

Berdasarkan hasil penelitian dan pembahasan, maka dapat diambil beberapa kesimpulan tingkat pendidikan tidak berpengaruh dan signifikan terhadap motivasi berzakat, infaq dan sedekah. Hal ini dibuktikan dengan nilai t hitung yang di dapat lebih kecil t tabel yaitu $-5,524<1,98896$. religiusitas berpengaruh positif dan signifikan terhadap motivasi berzakat, infaq dan sedekah. Hal ini dibuktikan $t$ hitung yang didapat lebih besar dari t tabel yaitu 4,464> 1,98896. pendapatan berpengaruh positif dan signifikan terhadap motivasi berzakat, infaq dan sedekah. Hal ini dibuktikan nilai t hitung yang didapat lebih besar dari t tabel yaitu 10,470 $>1,98896$. Tingkat pendidikan, religiusitas dan pendapatan secara simultan berpengaruh terhadap motivasi berzakat, infaq dan sedekah. Hal ini dibuktikan dengan nilai signifikansi $\mathrm{F}$ sebesar 0,000 yang berarti lebih kecil dari 0,05. Nilai $\mathrm{F}$ hitung yang diperoleh yaitu 78,456 lebih besar dari F tabel yaitu 2,71 (78,456 > 2,71). Besarnya hasil uji Adjusted $\mathrm{R}^{2}$ pada penelitian ini diperoleh nilai adjusted $\mathrm{R}^{2}$ sebesar 0,728 yang bearti bahwa besarnya pengaruh variabel tingkat pendidikan, variabel religiusitas dan variabel pendapatan adalah sebesar 72,8\%, sedangkan sisanya sebesar $27,2 \%$ dipengaruhi oleh faktor lain yang tidak dijelaskan dalam penelitian ini. 


\section{DAFTAR PUSTAKA}

Arikunto S. (1998). Prosedur Penelitian Suatu Pendekatan Praktek. Jakarta: PT Rineka Cipta.

Azwar, Saefuddin. (1998). Metode Penelitian, Yogyakarta: Pustaka Pelajar

B. Uno, Hamzah. (2008). Teori Motivasi Dan Pengukurannya. Jakarta: Bumi Aksara

Dimyati dan Mudjiono. (2009). Belajar dan Pembelajaran. Jakarta : PT Rineka Cipta

Fauzi, Muchammad. (2009). Metode Penelitian Kuantitatif. Semarang: Walisongo Press.

Fuadi. (2014). Zakat Dalam Sistem Hukum Pemerintahan Aceh. Yogyakarta: Depublish.

Ghozali, Imam. (2011). Aplikasi Analisis Multivariate Dengan Program SPSS. Semarang:Badan Penerbit Universitas Diponegoro.

Hamalik, oemar. (2004). Proses Belajar Mengajar, Jakarta : Bumi Aksara Hasibuan

Didin. (1998). Panduan Praktis Tentang Zakat Infak Sedekah. Jakarta: Gema Insani

Hasan, (2002). Metodologi Penelitian dan Aplikasinya. Jakarta: Ghalia Indonesia

Lijan Potak Sinambela. (2014). Metodologi Penelitian Kuantitatif. Yogyakarta: Graha Ilmu.

Margono. (2000). Penelitian kualitatif. Yogyakarta: Raja Grafindo Perrsada.

Muhammad. (2013). Metode Penelitian Ekonomi Islam Pendekatan Kuantitatif . Jakarta:Raja Grafindo Persada

Nata, Abuddin. (2000). Metodology Study Islam. Jakarta: Grafindo persada. Nofiaturrahmah, Fifi. (2015) "Pengumpulan Dan Pendayagunaan Zakat Infak Dan Sedekah". Ziswaf, Vol 2, No. 2.

Notoatmodjo. (2005). Metodologi Penelitian Kesehatan. Jakarta: Rineka Cipto.

Qardawy, Yusuf. (1999). Hukum Zakat. Bogor: Pustaka Litera Antar Nusa.

Retnowati, Wahyu Indah. (2007). Hapus Gelisah dengan Sedekah. Jakarta: Qultum Media.

Riduwan. (2013). Metode dan Teknik Menyusun Proposal Penelitian. Bandung: Alfabeta.

Shahnaz,Sabrina. (2015) "Penerapan Psak No.109 Tentang Pelaporan Keuangan 
Akuntansi Zakat, Infaq, Sedekah Pada Badan Amil Zakat Provinsi Sulawesi

Utara”. Jurnal EMBA, Vol 3, No. 4.

Sjechul, Hadi Permono. (1995), "Pemerintah Republik Indonesia Sebagai Pengelola Zakat", Jakarta: Pustaka fFrdaus.

Slamet, (2017). NU Dan Pemberdayaan Ekonomi Umat. Jakarta: Yayasan Lembaga Amil Zakat Infaq Dan Shadaqah Nahdhatul Ulama.

Soemitra,Andri. (2009). Bank Dan Lembaga Keuangan Syariah. Jakarta: Kencana Penada Media Group

Saefuddin.A.,M. 2011. Membumikan Ekonomi Islam. Jakarta: PT.PPA Consultans

Sabiq, Sayyid. (1987). Fikih Sunnah. Bandung: PT Alma'arif.

Sanusi, Muhammad. (2009). The Power Of Sedekah. Yogyakarta: Pustaka Insan Madani

Sugiyono. (2010). Metode Penelitian Kuantitatif Kualitatif dan R\&D. Bandung: Alfabeta. Undang-Undang RI Nomor 23 tahun 2011 tentang pengelolaan zakat Undang-Undang No. 20 tahun 2003 Tentang SPN

Wulansari, SintaDwi. (2014). “Analisis Peranan Dana Zakat Produktif Terhadap Perkembangan Usaha Mikro Mustahik (Penerima Zakat)". Universitas Dipenogoro, Semarang. Jurnal Ekonomi. Vol 3, No.1.

Yusuf, Qardawi, Hukum Zakat: Studi Komperatif Mengenai Status dan Filsafat ZakatBerdasarkan Qur'an dan Hadits. Jakarta: PT Mitra Kerjaya Indonesia.

Zuhri, Saifudin. (2012). "Zakat Di Era Reformasi (Tata Kelola Baru) UndangUndang Pengelolaan Zakat No 23 tahun 2011". Semarang : Fakultas Tarbiyah IAIN Walisongo.

www.nucare.id

www.nu.or.id 